\title{
ANALISA MANFAAT DAN KEMUDAHAN PENGGUNAAN GOOGLE TASK DI LINGKUNGAN AKADEMIK MENGGUNAKAN METODE TAM
}

\author{
Rizki Tri Prasetio \\ Universitas Adhirajasa Reswara Sanjaya \\ e-mail: rizki@ars.ac.id
}

\begin{abstract}
Abstrak
Google Task merupakan aplikasi pengingat dikembangkan oleh Google yang termasuk kedalam paket G Suite for Education. Bagi siswa kelas XI SMK Negeri 2 Bandung, penggunaan aplikasi pengingat seperti Google Task sangat membantu, karena dapat digunakan sebagai sarana pembelajaran. Tujuan dari penelitian ini untuk mengetahui sikap terhadap penerimaan aplikasi Google Task pada siswa kelas XI SMK Negeri 2 Bandung. Metode penelitian yang digunakan yaitu dengan metode Technology Acceptance Model (TAM) dengan 3 variabel, yaitu persepsi kemanfaatan (perceived usefulness), persepsi kegunaan (perceived ease of use), dan sikap penerimaan (attitude toward using). Populasi pada penelitian ini adalah siswa-siswa kelas XI SMK Negeri 2 Bandung sebanyak 252 orang dengan sampel sebanyak 100 orang. Hasil penelitian menunjukan bahwa persepsi kemanfaatan mempengaruhi sikap penerimaan dengan nilai korelasi sebesar 0,652 sementara persepsi kemudahan tidak mempengaruhi sikap penerimaan dengan nilai korelasi sebesar 0,008 dan persepsi kemanfaatan dan persepsi kegunaan mempengaruhi secara simultan terhadap variabel sikap penerimaan dengan tingkat hubungan Rsquare sebesar 0,427 atau dalam persentase sebesar $42,7 \%$, dan sisanya 0,573 atau dalam persentase sebesar $57,3 \%$ merupakan pengaruh yang diberikan oleh variabel lain diluar model penelitian ini.
\end{abstract}

Kata Kunci: Technology Acceptance Model, Google Task, G Suite Education

\begin{abstract}
Google Task is a reminder application developed by Google that is included in the G Suite for Education package. For $11^{\text {th }}$ grade students of SMK Negeri 2 Bandung, the use of reminder applications such as Google Task is very helpful, because it can be used as a learning tool. The purpose of this study was to determine attitudes toward acceptance of Google Task applications in 1 th $^{t}$ grade students of SMK Negeri 2 Bandung. The research method used is the Technology Acceptance Model (TAM) with 3 variables, namely perceived usefulness, perceived ease of use, and attitude toward using. The population in this study were students of 1 th $^{t}$ grade students of SMK Negeri 2 Bandung in total of 252 people with a sample of 100 people. The results showed that the perceived usefulness affects the attitude of acceptance with a correlation value of 0.652 while the perceived ease of use does not affect the attitude of acceptance with a correlation value of 0.008 and the perceived usefulness and perceived ease of use influence simultaneously on the attitude toward using variable with a relationship level of Rsquare of 0.427 or in a percentage of $42,7 \%$, and the remaining 0.573 or a percentage of $57.3 \%$ is the influence exerted by other variables outside this research model.
\end{abstract}

Keywords: Technology Acceptance Model, Google Task, G Suite Education

\section{Pendahuluan}

Kemajuan teknologi informasi dan komunikasi berjalan sangat cepat, khususnya di Indonesia. Semakin berkembangnya teknologi informasi dan komunikasi membawa pengaruh terhadap keterampilan sosial masyarakat baik bersifat positif maupun negatif.
Pada tahun 2017, Asosiasi Penyelenggara Jasa Internet Indonesia (APJII) merilis data mengenai peningkatan dan perilaku pengguna internet Indonesia. Tahun 2017 jumlah pengguna internet di Indonesia sudah mencapai 143,26 juta jiwa dari total populasi penduduk indonesia yang berjumlah 262 juta jiwa. 
Angka tersebut menunjukan bahwa peningkatan penggunaan internet di Indonesia mencapai 54,68\%. Angka tersebut meningkat dimana di tahun 2016 hanya sebesar $51,8 \%$ dengan jumlah pengguna sebesar 132,7 juta jiwa dari populasi sebanyak 256,2 juta jiwa.

APJII juga merilis data penggunaan internet dikalangan siswa, karena semakin meningkatnya jenjang pendidikan, maka kebutuhan siswa umur 13-18 tahun dalam mengakses internet semakin berkembang. Hal ini dapat dilihat pada penggunaan internet pada siswa SMP/ Mts atau sederajat ada di angka $48,53 \%$, pada siswa SMA/MA atau sederajat ada di angka $70,54 \%$.

Untuk Frekuensi penggunaan internet rata-rata pengguna internet di Indonesia mengakses media sosial selama 1-3 jam perhari yaitu $43,89 \%$ dari total seluruh pengguna Internet di Indonesia (APJII, 2017)

Dalam penelitian ini, Google Task diteliti karena telah diunduh oleh lebih dari 5 juta orang di seluruh dunia. Pada penelitian ini akan dianalisa pengaruh manfaat dan kemudahan terhadap sikap penerimaan aplikasi Google Task di kalangan siswa -siswi kelas XI SMK Negeri 2 Bandung menggunakan metode Technology Acceptance Model (TAM) dalam kegunaannya sebagai sarana pembelajaran.

Bagi siswa kelas XI SMK Negeri 2 Bandung, penggunaan Google Task dianggap membantu, karena selain digunakan sebagai sarana pengingat, Google Task juga dapat digunakan sebagai sarana pembelajaran.

TAM merupakan metode yang digunakan dalam penelitian ini. Metode TAM ini sudah banyak digunakan dalam penelitian-penelitian sebelumnya baik dalam pemerintahan maupun pendidikan. Menurut Davis TAM menawarkan sebuah teori sebagai landasan untuk mempelajari dan memahami perilaku pemakai dalam menerima dan menggunakan sistem informasi (Hidayat \& Junianto, 2017).

Beberapa penelitian sebelumnya yang menggunakan metode TAM salah satunya dilakukan oleh A. Rizal (2014) tentang analisis penerapan Project Management Information System (PMIS) dengan studi kasus PT. Indosat, Tbk.
Metode TAM disini digunakan untuk mengetahui perilaku user terhadap sistem teknologi informasi baru. Hasil penelitian mengemukakan bahwa implikasi dari hubungan kausal antara faktor-faktor didalam PMIS yaitu, variabel laten Perceived Easy of Use (PEOU) berpengaruh pada variabel Perceived Usefulness (PU).

Selanjutnya ada penelitian yang dilakukan oleh Kurniawati et al (2017) tentang penerapan TAM terhadap minat penggunaan mobile banking. Dimana metode TAM disini menggunakan model yang telah dimodifikasi untuk menganalisa faktor-faktor yang dapat mempengaruhi persepsi mahasiswa tentang intensi untuk menggunakan aplikasi mobile banking untuk mendukung aktifitas sehari-hari mereka. Hasil penelitian mengemukakan bahwa persepsi kegunaan berpengaruh terhadap minat perilaku penggunaan mobile banking dan gender tidak berpengaruh terhadap persepsi kegunaan dan persepsi kemanfaatan.

Dari penjelasan tersebut, maka pada penelitian ini akan diteliti sejauh mana Google Task dapat diterima oleh siswasiswi kelas XI SMK Negeri 2 Bandung sebagai sarana pembelajaran dimana variabel yang dipakai yaitu persepsi kemudahan penggunaan (perceived ease of use), persepsi kegunaan (perceived usefulness) dan sikap terhadap penggunaan aplikasi Google Task (attitude toward using).

\section{Metode Penelitian \\ Technology Acceptance Model}

Menurut Wijaya (2005) dalam jurnal (Satrio et al., 2017) TAM mendeskripsikan terdapat dua faktor yang secara dominan mempengaruhi integrasi teknologi. Yang pertama adalah persepsi pengguna terhadap manfaat teknologi. Faktor kedua adalah persepsi pengguna terhadap kemudahan penggunaan teknologi. Kedua faktor tersebut mempengaruhi kemauan untuk memanfaatkan teknologi. Selanjutnya, kemauan untuk memanfaatkan teknologi akan mempengaruhi teknologi yang sesungguhnya.
Dalam jurnal (Rizal, 2014) mengatakan Technology Acceptance Model (TAM), diperkenalkan pertama kali oleh Davis pada tahun 1989. 
TAM dibuat khusus untuk pemodelan adopsi pengguna system informasi. Menurut Davis (1989), tujuan utama TAM adalah untuk mendirikan dasar penelusuran pengaruh faktor eksternal terhadap kepercayaan, sikap (personalisasi), dan tujuan pengguna komputer.

\section{a. Perceived Usefulness}

Menurut jogiyanto (2007) dalam jurnal (Dewi \& Kt.Warmika, 2016) persepsi manfaat (Perceived Usefulness) merupakan suatu kepercayaan tentang proses pengambilan keputusan. Sedangkan dalam jurnal (Siahaan \& Prihandoko, 2019) Persepsi kemanfaatan adalah dimana suatu penggunaan teknologi dipercaya dapat mendatangkan manfaat bagi penggunanya.

\section{b. Perceived Ease of Use}

Dalam jurnal (Rukmiyati \& Budiartha, 2016) perceived ease of use merupakan tingkat seberapa besar teknologi komputer dirasakan relatif mudah untuk dipahami dan digunakan. Hal ini memperlihatkan bahwa jika pemakai sistem informasi merasa bahwa menggunakan sistem tersebut mudah, maka mereka tidak memerlukan effort banyak untuk menggunakannya, sehingga merekan akan lebih banyak waktu untuk mengerjakan hal lain yang kemungkinan akan meningkatkan kinerja mereka secara keseluruhan. Sedangkan dalam jurnal (Bimaniar et al., 2018) persepsi kemudahan menjelaskan sejauh mana pengguna meyakini bahwa penggunaan suatu sistem informasi mudah dan tidak perlu usaha yang keras.

\section{c. Attitude Toward Using}

Dalam jurnal (Jundullah et al., 2019) Attitude Toward Using atau sikap terhadap penerimaan adalah sifat terhadap perilaku sebagai perasaan positif atau negatif seseorang jika harus melakukan perilaku yang akan ditentukan. Sedangkan menurut Wibowo (2006) dalam jurnal (Hidayat \& Junianto, 2017) Attitude Toward Using dikonsepkan sebagai sikap terhadap penggunaan sistem yang berbentuk penerimaan atau penolakan sebagai dampak bila seseorang menggunakan teknologi dalam pekerjaannya.

\section{Tahapan Penelitian}

Tahapan penelitian yang di lakukan adalah tahapan penelitian deskriptif yang bertujuan untuk membuat secara sistematis, faktual, dan akurat mengenai fakta-fakta dan sifat-sifat populasi atau daerah tertentu. Tahapan penelitiannya yaitu:

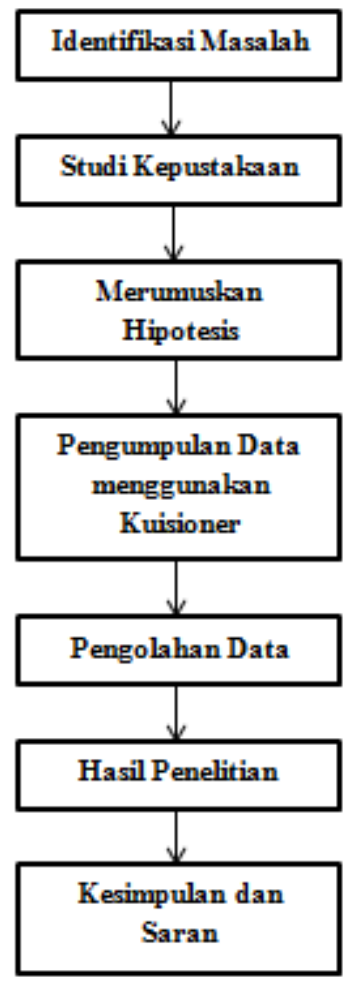

Gambar 1. Metode Penelitian

\section{Instrument Penelitian}

Menurut Sugiyono dalam (Hidayat \& Junianto, 2017) mengemukakan bahwa "Variabel penelitian adalah segala sesuatu yang berbentuk apa saja yang ditetapkan oleh peneliti untuk dipelajari sehingga diperoleh informasi tentang hal tersebut kemudian ditarik kesimpulannya" dalam jurnal tersebut Sugiyono juga mengemukakan berdasarkan hubungan antara satu variabel dengan variabel lain maka macam-macam variabel dalam penelitian yaitu variabel independen, variabel dependen, variabel moderator, variabel interventing dan variabel kontrol. Dalam penelitian ini variabel yang digunakan meliputi:

\section{a. Variabel Independen}

Menurut Sugiyono (2013) dalam (Hidayat \& Junianto, 2017) "Variabel ini sering disebut sebagai variabel stimulus, prediktor, antecedent. Dalam bahasa Indonesia sering disebut sebagai variabel bebas". Variabel bebas adalah variabel yang mempengaruhi atau yang menjadi sebab perubahannya atau timbulnya variabel dependen (terikat). Dalam 
penelitian ini yang gunakan menjadi variabel bebas adalah Perceived Usefulness $\left(\mathrm{X}_{1}\right)$ dan Perceived Ease of Use $\left(\mathrm{X}_{2}\right)$.

b. Variabel Dependen

Dalam (Hidayat \& Junianto, 2017) Variabel ini sering disebut dengan variabel output, kriteria, konsekuen. Dalam bahasa Indonesia sering disebut sebagai variabel terikat. Variabel terikat merupakan variabel yang dipengaruhi atau yang menjadi akibat karena adanya variabel bebas. Dalam penelitian ini yanggunakan menjadi variabel terikat adalah Attitude Toward Using (Y).

\section{Metode Pengumpulan Data, Populasi dan Sampel Penelitian \\ a. Metode Pengumpulan Data}

Menurut Sugiyono (2006) dalam (Hidayat \& Junianto, 2017) Pengumpulan data dapat dilakukan dalam berbagai setting, berbagai sumber, dan berbagai cara. Bila dilihat dari setting-nya, data dapat dikumpulkan pada setting alamiah (natural setting). Bila dilihat dari sumber datanya, maka pengumpulan data dapat menggunakan sumber primer, dan sumber sekunder. Selanjutnya bila dilihat dari segi teknik pengumpulan data dapat dilakukan dengan interview (wawancara), kuisioner (angket), observasi (pengamatan), dan gabungan ketiganya.

Berdasarkan cara pengumpulan data, maka cara pengumpulan data dalam penelitian ini meliputi:

1) Observasi

Menurut Nazir dalam (Kusumaningtyas \& Rahajeng, 2017) pengumpulan data dengan observasi langsung atau dengan pengamatan langsung yaitu "cara pengambilan data dengan menggunakan mata tanpa ada pertolongan alat standar lain untuk keperluan tersebut.

2) Kuisioner

Menurut Nazir dalam (Kusumaningtyas \& Rahajeng, 2017) kuisioner adalah "sebuah set pertanyaan yang secara logis berhubungan dengan masalah penelitian, dan tiap pertanyaan merupakan jawaban-jawaban yang mempunyai makna dalam menguji hipotesis".

3) Studi Pustaka

Menurut Nazir dalam (Kusumaningtyas \& Rahajeng, 2017) studi pustaka adalah teknik pengumpulan data dengan mengadakan studi penelaahan terhadap buku-buku, literatur-literatur, catatan-catatan, dan laporan-laporan yang ada hubungannya dengan masalah yang dipecahkan".

\section{b. Populasi Penelitian}

Populasi adalah keseluruhan atau totalitas objek psikologis yang dibatasi kriteria tertentu. Populasi yang digunakan pada penelitian ini yaitu siswa kelas XI SMK Negeri 2 Bandung yang berjumlah total 252 siswa.

\section{c. Sampel Penelitian}

Menurut Sugiyono (2013) dalam (Akram et al., 2017) adalah "bagian dari jumlah dan karakteristik yang dimiliki populasi tersebut". Sedangkan dalam (Suryani, 2017) sampel adalah "sebagian kecil dari anggota populasi yang diambil dengan prosedur tertentu yang secara representatif mewakili kebenaran populasi".

Dalam penelitian ini digunakan teknik nonprobability sampling dengan pendekatan sampling purposive. Nonprobability sampling itu sendiri menurut Sugiyono (2006) dalam (Hidayat \& Junianto, 2017) adalah "teknik pengambilan sampel yang tidak memberi peluang/ kesempatan sama bagi setiap unsur atau anggota populasi untuk dipilih menjadi sampel". Sedangkan sampling purposive adalah "teknik penentuan sampel dengan pertimbangan tertentu". Dalam hal ini penarikan sampel dilalukan dengan pertimbangan jumlah populasi yang terlalu banyak, serta adanya keterbatasan waktu dan biaya. Yang menjadi sampel dalam penelitian ini adalah siswa kelas XI SMK Negeri 2 Bandung yang menggunakan Google Task.

Dalam penelitian ini, diambil beberapa sampel dari keseluruhan jumlah populasi dikarenakan adanya beberapa faktor, diantaranya keterbatasan waktu dan biaya. Oleh karena itu digunakan rumus Slovin untuk menentukan jumlah sampel sebagai berikut:

$$
n=\frac{N}{1+\left(N x e^{2}\right)}
$$

Sumber: Metode Slovin dalam (Hidayat \& Junianto, 2017)

$n \quad=$ Ukuran sampel

$N \quad=$ Ukuran populasi

$e^{2} \quad=$ Kelonggaran ketelitian karena

kesalahan sampel yang dapat ditolerir

e $\quad=10 \%=0,1$

Dengan demikian, dapat dihitung

ukuran sampel yang diperoleh 


$$
\begin{gathered}
n=\frac{N}{1+\left(N x e^{2}\right)} \\
n=\frac{252}{1+(252 \times 0,01)} \\
n=\frac{252}{3,52} \\
n=71,59
\end{gathered}
$$

Dari perhitungan tersebut, dapat ditemukan jumlah sampel minimal sebesar 71,59 dapat dibulatkan menjadi 72 . Sementara itu, diambil sampel sebesar 100 untuk dijadikan responden.

\section{Hasil dan Pembahasan \\ 3.1. Analisa Deskriptif}

Dalam jurnalnya (Nurmalasari \& Wulandari, 2018) mengemukakan bahwa data yang berhasil dikumpulkan akan diolah menggunakan teknik statistika deskriptif yang disajikan dalam bentuk distribusi, frekuensi meliputi skor rata-rata, media, modus dan skor maksimum minimum.

Sedangkan menurut Misbahuddin \& Hasan (2013) dalam (Hidayat \& Junianto, 2017) analisis deskriptif merupakan "bentuk analisis data untuk menguji generalisasi hasil penelitian yang didasarkan atas satu sampel". Analisis deksriptif ini dilakukan melalui pengujian hipotesis deskriptif. Hasilnya adalah apakah hipotesis penelitian dapat digeneralisasikan atau tidak. Jika hipotesis nol $(\mathrm{H} 0)$ diterima, berarti hasil penelitian dapat digeneralisasikan.

Data yang diperoleh melalui penyebaran kuesioner terhadap siswa kelas XI SMK Negeri 2 Bandung diolah secara statistika deskriptif untuk mengetahui tanggapan responden. Tanggapan responden tersebut dikategorikan ke dalam 5 (lima) tingkatan yang terdiri dari "Sangat Tidak Setuju", "Tidak Setuju", "Netral", "Setuju", "Sangat Setuju" dengan perhitungan dasar sebagai berikut"

$$
\text { Panjang kelas }=\frac{\text { data terbesar }- \text { data terkecil }}{\text { jumlah kelas interval }}
$$

Sedangkan, jika diaplikasikan pada penelitian ini, maka perhitungan statistik deskriptif tersebut sebagai berikut:

Keterangan:

$$
\text { interval skor kategori }=\frac{\text { Sit }- \text { Sir }}{\text { Jumlah kategor } i}
$$

a) Sit (skor ideal tertinggi)

$=$ skor tertinggi $\mathrm{x}$ jumlah sampel $\mathrm{x}$ jumlah pernyataan

b) Sir (skor ideal rendah)
$=$ skor terendah $\mathrm{x}$ jumlah sampel $\mathrm{x}$ jumlah pernyataan

\subsection{Analisa Statistik}

Menurut Misbahuddin \& Hasan dalam (Hidayat \& Junianto, 2017) alat utama yang sering digunakan dalam analisis data adalah metode statistik.

\subsection{Uji Asumsi Klasik}

Uji Asumsi Klasik digunakan untuk mengetahui apakah data penelitian dapat dipakai atau tidak. Uji yang digunakan oleh pada penelitian adalah uji normalitas, uji autokorelasi, uji multikolinearitas dan uji heterokedastisitas.

\section{a. Uji Normalitas}

Uji normalitas digunakan untuk mengetahui bentuk distribusi data penelitian tersebut berdistribusi normal atau tidak normal. Indikator yang digunakan adalah membandingkan antara hasil analisis uji normalitas dengan 0,05 . Apabila hasilnya lebih besar dari 0,05 maka dapat dikatakan data berdistribusi normal, artinya alat analisis selanjutnya harus menggunakan statistic parametik. Apabila

\begin{tabular}{|c|c|c|c|c|}
\hline & \multirow{3}{*}{$\begin{array}{l}\text { Pencined } \\
\text { Chophinear } \\
100\end{array}$} & \multirow{3}{*}{$\begin{array}{c}\begin{array}{c}\text { Perceniad Eas } \\
\text { oflir }\end{array} \\
100\end{array}$} & \multirow{3}{*}{\begin{tabular}{|c} 
AmindeTreand \\
Cing \\
100
\end{tabular}} \\
\hline & & & & \\
\hline $\mathrm{s}$ & & & & \\
\hline \multirow{2}{*}{ 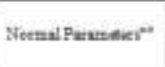 } & Meas & 10,5786 & 10,2793 & 10,3163 \\
\hline & Sol Devirhor: & 2,13914 & 2,40641 & 2,24579 \\
\hline \multirow{3}{*}{$\begin{array}{l}\text { Mourtunvan } \\
\text { Differmers }\end{array}$} & Abaolats & 0.074 & 074 & 056 \\
\hline & Panitive & .074 & .058 &, 056 \\
\hline & Negever & -942 & $-0,074$ & .048 \\
\hline \multicolumn{2}{|l|}{ TntStratic } & 074 & 074 & .056 \\
\hline \multicolumn{2}{|l|}{ Arrap Sit (2tailed) } & $200^{40}$ & $209^{\circ}$ & $200^{\circ}$ \\
\hline \multicolumn{5}{|c|}{ 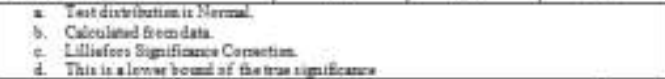 } \\
\hline
\end{tabular}
hasil uji menunjukan angka 0,05 maka alat analisis yang harus digunakan adalah statistic non-parametik. Hasil uji normalitas dapat dilihat pada tabel 1 :

Tabel 1. Hasil Uji Normalitas

Berdasarkan tabel 1 menunjukan bahwa pada variabel $X_{1}, X_{2}, Y$ berdistribusi normal dan menggunakan statistic parametric, dapat dilihat pada Asymp. Sig. (2-tailed) yaitu $0,200\left(X_{1}\right), 0,200\left(X_{2}\right), 0,200$ (Y) hasil tersebut diatas 0,05 , artinya variabel Perceived Usefulness, Perceived Ease of Use, dan Attitude Toward Using berdistribusi normal dan menggunakan statistic parametic.

\section{b. Uji Autokorelasi}

Uji Autokorelasi bertujuan untuk mengetahui ada tidaknya korelasi antara 
variabel penganggu pada periode tertentu dengan variabel sebelumnya. Untuk data time series autokorelasi sering terjadi. Tapi untuk data crossection jarang terjadi karena variabel penganggu satu berbeda dengan yang lain. Gejala autokorelasi ini dapat dideteksi dengan menggunakan uji Durbin Watson. Jika nilai DW diantara -2 sampai +2 dan jika du $\leq \mathrm{DW} \leq 4$-du maka tidak terjadi autokorelasi. Hasil uji Durbin Watson (DW) penelitian ini dapat dilihat pada tabel 2:

Tabel 2. Hasil Uji Autokorelasi

\begin{tabular}{|c|c|c|c|c|c|}
\hline \multicolumn{6}{|c|}{ Model Summary? } \\
\hline Medd & il. & R sopsor & $\begin{array}{l}\text { Adpassed IR } \\
5_{\text {patre }}\end{array}$ & $\begin{array}{l}\text { Sid Enorst the } \\
\text { Extimit }\end{array}$ & Dartin-Wwan \\
\hline 1 & .054 & A27 & Ais & 1.71978 & 1,878 \\
\hline
\end{tabular}

Berdasarkan tabel 2 uji autokorelasi dilakukan dengan melihat nilai dari angka Durbin-Watson yang nilainya sebesar 1.876, maka tidak terjadi autokorelasi.

\section{c. Uji Multikolinearitas}

Multikolinearitas artinya antara variabel independen yang terdapat dalam model memiliki hubungan yang sempurna atau mendekati sempurna atau koefisien korelasinya tinggi. Model untuk menguji ada tidaknya multikolinearitas dapat dilihat dari Variance Inflation Factor (VIF). Batas nilai VIF adalah 10, apabila nilai VIF lebih dari 10 maka disimpulkan terjadinya multikolinearitas. Hasil uji multikolinearitas dapat dilihat pada tabel 3 .

Berdasarkan tabel 3 nilai tolerance dan VIF yang diperoleh menunjukan tidak ada korelasi yang sangat kuat antara variabel bebas dimana nilai tolerance sebesar $0,952>a$ dan nilai VIF sebesar $1,050<10$ maka dapat disimpulkan tidak terdapat multikolinearitas antara kedua variabel bebas.

Tabel 3. Hasil Uji Multikolinearitas Coetficients"

\begin{tabular}{|c|c|c|c|c|c|c|c|c|}
\hline & \multirow{2}{*}{ Moted } & \multicolumn{2}{|c|}{ 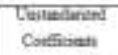 } & \multirow{2}{*}{ 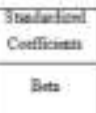 } & \multirow{2}{*}{. } & \multirow{2}{*}{ so } & \multicolumn{2}{|c|}{ Collenen Stumba } \\
\hline & & B & $\begin{array}{l}\text { IH } \\
\text { Enar }\end{array}$ & & & & Talume & VIF \\
\hline \multirow{3}{*}{1} & TCantate & 2000 & 1046 & & $29 n$ & 100 & & \\
\hline & $\begin{array}{l}\text { Fomether } \\
\text { oxpliven }\end{array}$ & S98 & .94 & 002 & $8,2 y$ & 500 & 952 & 1,290 \\
\hline & 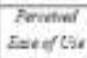 & काषा & 894 & set & .297 & 923 & 982 & 1030 \\
\hline
\end{tabular}

\section{d. Uji Heterokedastisitas}

Heterokedastisitas dilakukan untuk apakah dalam sebuah regresi terjadi ketidaksamaan varians dari residual suatu pengamatan ke pengamatan lain. Agar koefisien-koefisien regresi tidak menyesatkan, maka situasi heteroskedastisitas tersebut harus dihilangkan dari regresi. Uji ini dilakukan untuk melihat pola scatterplot, jika tidak ada pola yang jelas, serta titik-titik yang menyebar diatas dan dibawah angka 0 pada sumbu $\mathrm{Y}$, maka tidak terjadi heterokedastisitas. Hasil uji heterokedastisitas dapat dilihat pada gambar 2:

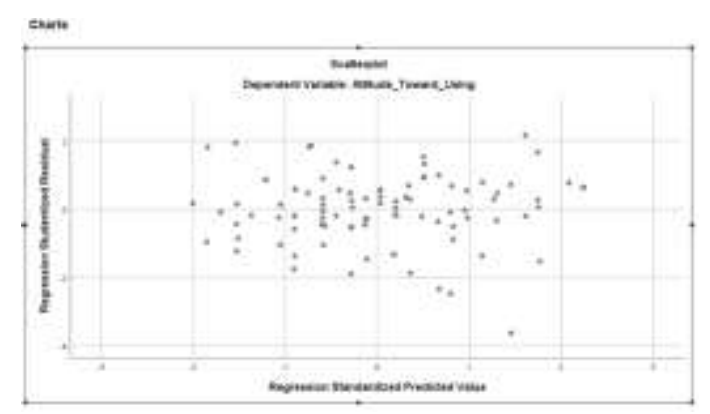

Gambar 2. Grafik Heterokedastisitas

Berdasarkan Pola Gambar 2 menjelaskan bahwa titik-titik data menyebar diatas dan dibawah angka nol, titik-titik data tidak mengumpul hanya diatas atau dibawah saja, penyebaran titik-titik data tidak membentuk pola apapun. Sehingga dapat disimpulkan bahwa tidak terjadi heteroskedastisitas.

\subsection{Pengaruh Antar Variabel}

Berikut ini pengaruh antar variabel diantaranya analisis regresi linier berganda dan pengujian hipotesis.

\section{a. Analisis Regresi Linier Berganda}

Analisis Regresi Linier Berganda dalam penelitian ini digunakan untuk menerangkan besarnya pengaruh persepsi kemanfaatan, persepsi kegunaan terhadap sikap penerimaan penggunaan Google Task. Estimasi model regresi linier berganda ini menggunakan bantuan software IBM SPSS 25 dan diperoleh hasil output sebagi berikut: 
Tabel 4.Hasil Analisis Regresi Linier Berganda coetficients

\begin{tabular}{|c|c|c|c|c|c|c|c|c|}
\hline & \multirow{2}{*}{ Modd } & \multicolumn{2}{|c|}{ 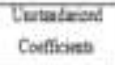 } & \multirow{2}{*}{ 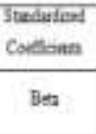 } & \multirow{2}{*}{$t$} & \multirow{2}{*}{ Sig. } & \multicolumn{2}{|c|}{ Collanery Sowites } \\
\hline & & B & $\begin{array}{l}3 \mathrm{H} \\
\mathrm{Han}\end{array}$ & & & & Talana: & VIF \\
\hline \multirow{3}{*}{1} & (Courtat) & 2,960 & 1046 & & 2832 & , 66 & & \\
\hline & $\begin{array}{l}\text { Prowed } \\
\text { lisplinat }\end{array}$ & sii & .054 & 652 & 1233 &, 260 & 92 & 1000 \\
\hline & $\begin{array}{l}\text { Prowe } \\
\text { Exeof the }\end{array}$ & 2091 & 104 & 308 & , 99 & 323 & 952 & 1,030 \\
\hline
\end{tabular}

Dari tabel tersebut dibentuk persamaan regresi linier sebagai berikut:

$\mathrm{Y}=\alpha+\rho \mathrm{yx} 1+\rho \mathrm{yx} 2$

Dimana:

$=2,963+0,652 X_{1}+0,008 X_{2}$

$\alpha=$ Konstanta

$\mathrm{Y}=$ Rasio variabel Dependent

Attitude Toward Using

$\mathrm{X}_{1} \quad=$ Variabel Perceived Usefulness

$\mathrm{X}_{2}=$ Variabel Ease of Use

1) Koefisien Perceived Usefulness yang secara langsung mempengaruhi

Attitude Toward Using sebesar 0,652 = 0,652 atau $65,2 \%$.

2) Koefisien Perceived Ease of Use yang secara langsung mempengaruhi

Attitude Toward Using sebesar 0,008 = 0,008 atau $0,8 \%$.

Tabel 5. Koefisien Model Summary

\begin{tabular}{|c|c|c|c|c|c|}
\hline Nedd & IR & R. Squser & $\begin{array}{l}\text { Adjused I } \\
\text { Snatre }\end{array}$ & $\begin{array}{l}\text { 5id Enor st the } \\
\text { Extinnit }\end{array}$ & Dartin-Wess \\
\hline 1 & DSt? & 427 & Ais & 1.71978 & 8.578 \\
\hline
\end{tabular}

Berdasarkan tabel 5, analisis yang digunakan untuk mengetahui seberapa kontribusi variabel $\mathrm{X}_{1}$ dan $\mathrm{X}_{2}$ mempengaruhi variabel $Y$ secara simultan. Koefisien yang terdapat pada persamaan tersebut dapat diketahui bahwa besarnya $\mathrm{R}$ square sebesar 0,427 atau 42,7\% mempunyai arti bahwa pengaruh Perceived Usefulness $\left(\mathrm{X}_{1}\right)$ dan Perceived Ease of Use $\left(\mathrm{X}_{2}\right)$ secara simultan (bersama-sama) terhadap Attitude Toward Using $(Y)$ adalah sebesar 42,7\% dan sisanya adalah pengaruh yang diberikan oleh variabel lain diluar penelitian ini.

\section{b. Pengujian Hipotesis}

1) Uji Parsial (Uji t)

Uji t dilakukan untuk mengetahui pengaruh masing-masing (parsial) variabel independen terhadap variabel dependen.
Uji $\mathrm{t}$ dilakukan dengan mengetahui nilai $\mathrm{t}$ tabel menggunakan rumus sebagai berikut:

$$
\text { t tabel }=t(a ; \mathrm{n}-\mathrm{k}-1)
$$

Keterangan:

a : Taraf signifikan 0,05

n : : Banyaknya sampel

k : Banyaknya variabel bebas

Dengan demikian

$\mathrm{T}$ tabel $=t(\mathrm{a} ; \mathrm{n}-\mathrm{k}-1)$

$=0,05 ; 100-2-1$

$=0,05 ; 97$

$=1,664$

Tabel 6. Distribusi Nilai Tabel $t$

\begin{tabular}{|c|c|c|c|c|c|}
\hline df & $\mathrm{t} 0,10$ & $\mathrm{t} 0,05$ & $\mathrm{t} 0,025$ & $\mathrm{t} 0,01$ & $\mathrm{t} 0,005$ \\
\hline 95 & 1.293 & 1.665 & 1988 & 2372 & 2.637 \\
\hline 96 & 1.292 & 1.664 & 1988 & 2372 & 2.636 \\
\hline 97 & 1.292 & 1.664 & 1988 & 2.371 & 2635 \\
\hline 98 & 1.292 & 1.664 & 1987 & 2371 & 2.635 \\
\hline 99 & 1.292 & 1.664 & 1987 & 2.370 & 2.634 \\
\hline
\end{tabular}

a) Pengujian hipotesis pengaruh Perceived Usefulness terhadap Attitude Toward Using. Pada pengujian ini akan diuji pengaruh Perceived Usefulness terhadap Attitude Toward Using secara parsial. Nilai tabel diperoleh dari tabel tingkat kepercayaan $\alpha=0,05 \quad(5 \%)$ dengan hipotesis sebagai berikut:

HO : Tidak adanya pengaruh secara signifikan antara kemanfaatan persepsian (Perceived usefulness) terhadap sikap penerimaan (attitude toward using) penggunaan Google Task sebagai sarana pembelajaran.

$\mathrm{Ha}$ : Terdapat pengaruh secara signifikan antara kemanfaatan persepsian (Perceived usefulness) terhadap sikap penerimaan (attitude toward using) penggunaan Google Task sebagai sarana pembelajaran.

Tabel 7. Hasil Uji Signifikasi parsial (uji t) Perceived Usefulness terhadap Attitude Toward Using Coefficients

\begin{tabular}{|c|c|c|c|c|c|c|c|c|}
\hline & \multirow{2}{*}{ Moda } & \multicolumn{2}{|c|}{$\begin{array}{l}\text { Tintaninged } \\
\text { Crefficents }\end{array}$} & \multirow{2}{*}{$\begin{array}{c}\text { Saludined } \\
\text { Coefficiarts } \\
\text { Bete }\end{array}$} & \multirow{2}{*}{$t$} & \multirow{2}{*}{ Sig } & \multicolumn{2}{|c|}{ Colfreanty Schistios } \\
\hline & & B & $\begin{array}{l}\text { Stid } \\
\text { Enot }\end{array}$ & & & & Twlane: & VIF \\
\hline \multirow{3}{*}{1} & (Cocatat) & 2.969 & 1,045 & & 21312 & 966 & & \\
\hline & $\begin{array}{l}\text { Probived } \\
\text { Usghines: }\end{array}$ & 608 & 104 & $=652$ & 8.233 & $\mathrm{SCO}$ & 952 & 1060 \\
\hline & $\begin{array}{l}\text { Pancinal } \\
\text { Exe of the }\end{array}$ & .007 & 9074 & , $M t$ & 097 & 923 & 952 & 1060 \\
\hline
\end{tabular}


Berdasarkan tabel 7 tersebut diketahui nilai signifikan untuk pengaruh Perceived Usefulness terhadap Attitude Toward Using adalah sebesar 0,000 < 0,05 dan terlihat nilai hitung sebesar $8,233>\mathrm{t}$ tabel 1,664. Maka HO ditolak dan $\mathrm{Ha}$ diterima sehingga dapat disimpulkan bahwa terdapat pengaruh $\mathrm{X}_{1}$ terhadap $\mathrm{Y}$.

b) Pengujian Hipotesis Pengaruh Perceived Ease of Use terhadap Attitude Toward Using. Berdasarkan tabel IV.31 tersebut diketahui nilai signifikan untuk pengaruh Perceived Ease of Use terhadap Attitude Toward Using adalah sebesar 0,923>0,05 dan terlihat nilai hitung sebesar $0,097<\mathrm{t}$ tabel 1,664. Maka H0 diterima dan $\mathrm{Ha}$ ditolak, sehingga dapat disimpulkan bahwa tidak terdapat pengaruh $\mathrm{X}_{2}$ terhadap Y.

HO : Tidak adanya pengaruh secara signifikan antara kemudahan persepsian (perceived easy of use) terhadap sikap penerimaan (attitude toward using) penggunaan Google Task sebagai sarana pembelajaran.

$\mathrm{Ha}$ : Terdapat adanya pengaruh secara signifikan antara kemudahan persepsian (perceived easy of use) terhadap sikap penerimaan (attitude toward using) penggunaan Google Task sebagai sarana pembelajaran.

2) Pengujian Secara Simultan (Uji f)

Uji $f$ bertujuan untuk mengetahui ada tidaknya pengaruh simultan (bersamasama) yang diberikan variabel bebas $(X)$ terhadap variabel terikat $(Y)$. Uji f dilakukan dengan mengetahui ftabel menggunakan rumus sebagai berikut:

Keterangan:

$$
\mathrm{f} \text { tabel }=\mathrm{F}(\mathrm{k} ; \mathrm{n}-\mathrm{k}-1)
$$

n : Banyaknya sampel

$\mathrm{k} \quad$ : Banyaknya variabel bebas

Dengan demikian

$\mathrm{f}$ tabel $=F(k ; n-k-1)$

$$
=\mathrm{F}(2 ; 100-2-1)
$$$$
=2 ; 97
$$

Tabel 8. Distribusi nilai $f$

\begin{tabular}{|c|c|c|c|c|}
\hline Df & 1 & 2 & 3 & 4 \\
\hline 96 & 3.94 & 3.09 & 2.70 & 2.47 \\
\hline 97 & 3.94 & 3.09 & 2.70 & 2.47 \\
\hline 98 & 3.94 & 3.09 & 2.70 & 2.46 \\
\hline
\end{tabular}

Hasil uji $f$ pada penelitian ini dapat dilihat dari tabel 9:

\begin{tabular}{|c|c|c|c|c|c|c|}
\hline & MFodel & Stm of Syanes: & df & $\begin{array}{l}\text { Maen } \\
\text { Squarer }\end{array}$ & F & Sig \\
\hline \multirow{3}{*}{1} & Regessiat & 211,662 & 2 & 105,831 & 35,733 &, $\mathrm{NOH}^{\circ}$ \\
\hline & Reaidaal & 283,923 & 96 & 2958 & & \\
\hline & Tote! & 495,592 & 98 & & & \\
\hline
\end{tabular}

Tabel 9. Pengujian $\mathrm{f}$ simultan

berikut:

Perumusan Hipotesis 3 sebagai

HO : Tidak terdapat pengaruh signifikan antara Perceived Usefulness dan Perceived Ease of Use terhadap Attitude Toward Using.

$\mathrm{Ha}$ : Terdapat pengaruh signifikan antara Perceived Usefulness dan Perceived Ease of Use terhadap Attitude Toward Using.

Pengujian berdasarkan tabel 9 , diketahui nilai signifikan untuk pengaruh $X_{1}$ dan $\mathrm{X}_{2}$ secara simultan terhadap $\mathrm{Y}$ adalah sebesar $0,00<0,05$ dan nilai $f$ hitung $35,783>\mathrm{f}$ tabel 3,09 sehingga dapat disimpulkan bahwa $\mathrm{HO}$ ditolak dan $\mathrm{Ha}$ diterima, sehingga hipotesis berbunyi terdapat pengaruh signifikan antara variabel Perceived Usefulness $\left(\mathrm{X}_{1}\right)$ dan Perceived Ease of Use $\left(\mathrm{X}_{2}\right)$ terhadap Attitude Toward Using $(\mathrm{Y})$ secara simultan (bersama-sama).

\section{c. Uji Rsquare}

Uji Rsquare dilakukan untuk mengetahui seberapa besarnya hubungan yang diberikan variabel independen $\left(X_{1}\right)$ dan $\left(X_{2}\right)$ terhadap variabel dependen $(Y)$. Hasil dari uji rsquare dapat dilihat pada tabel 10:

Tabel 10. Hasil Uji Rsquare

\begin{tabular}{|c|c|c|c|c|c|}
\hline Madal & R & R. Squave & $\begin{array}{c}\text { Adjustad R. } \\
\text { Savurs }\end{array}$ & $\begin{array}{l}\text { 3tid. Error of the } \\
\text { Estingse }\end{array}$ & Darbin-Watsun \\
\hline I & 654 & 427 & .415 & 1,71976 & 1.876 \\
\hline
\end{tabular}
Model Summarn ${ }^{b}$

b. Depardent Variabl: Antivids Toverd ting 
Berdasarkan tabel 10 dapat dilihat Rsquare sebesar 0,427 . Artinya terdapat pengaruh Perceived Usefulness $\left(\mathrm{X}_{1}\right)$, Perceived Ease of Use $\left(\mathrm{X}_{2}\right)$ secara simultan terhadap Attitude Toward Using (Y) sebesar 0,427 atau dalam persentase sebesar $42,7 \%$ dan sisanya dipengaruhi variabel lain yang berasal dari luar model penelitian.

\section{d. Analisis Jalur}

Model analisis jalur digunakan untuk menganalisis pola hubungan antar variable dengan tujuan untuk mengetahui pengaruh langsung maupun tidak langsung seperangkat variabel bebas (eksogen) terhadap variabel terikat (endogen).

\section{Kesimpulan}

Berdasarkan hasil penelitian tentang pengaruh persepsi kemanfaatan dan persepsi kemudahan terhadap sikap penerimaan penggunaan Google Task sebagai sarana pembelajaran, maka dapat disimpulkan beberapa hal sebagai berikut:

a. Variabel persepsi kemanfaatan (Perceived Usefulness) mempengaruhi variabel sikap penerimaan (Attitude Toward Using) dengan nilai hubungan korelasi kuat sebesar 0,652 yang berarti semakin baik persepsi kemanfaatan (Perceived Usefulness) maka dapat meningkatkan sikap penggunaan (Attitude Toward Using).

b. Variabel persepsi kegunaan (Perceived Ease of Use) tidak mempengaruhi sikap penggunaan (Attitude Toward Using) dengan nilai hubungan korelasi sebesar 0,008 .

c. Variabel persepsi kemanfaatan (Perceived Usefulness) dan persepsi kemudahan (Perceived Ease of Use) mempengaruhi sikap penggunaan (Attitude Toward Using) secara simultan sebesar 0,427 atau dalam persentase $42,7 \%$ dan sisanya dipengaruhi variabel lain yang berasal dari luar model penelitian.

\section{Referensi}

Akram, Animah, \& Basuki, P. (2017). PENGARUH KUALITAS SISTEM INFORMASI, KUALITAS INFORMASI, KEPUASAN PENGGUNA, DAN KOMPETENSI SUMBER DAYA MANUSIA TERHADAP PENGGUNAAN SISTEM ERP (ENTERPRISE RESOURCE

\section{PLANNING) BERBASIS TAM (TECHNOLOGY ACCEPTANCE MODEL), (September).}

APJII. (2017). Penetrasi \& perilaku pengguna internet indonesia.

Bimaniar, I. M., Mawarni, A., Agushybana, Fa., \& Dharmawan, Y. (2018). Pengaruh Persepsi Kemudahan Penggunaan dan Persepsi Kemanfaatan Dengan Niat Untuk Menggunakan Sistem Informasi Manajemen Surveillance Kesehatan Ibu dan Anak, 6.

Davis, F.D. (1989), "Perceived usefulness, perceived ease of use and use acceptance of information technology", Management Science, Vol. 35, No. 8, pp. 982-1003

Dewi, N. M. A. P., \& Kt.Warmika, I. G. (2016). Peran persepsi kemudahan penggunan, persepsi manfaat dan perspsi resiko terhadap niat menggunakan, 5(4), 2606-2636.

Hidayat, A. R., \& Junianto, E. (2017). Pengaruh Gadget Terhadap Prestasi Siswa SMK Yayasan Islam Tasikmalaya, 4(2), 163-173.

Jundullah, M., Umar, R., \& Yudhana, A. (2019). ANALISIS PENERIMAAN SISTEM E-LEARNING SMK NEGERI 4 KOTA SORONG DENGAN MENGGUNAKAN TECHNOLOGY ACCEPTANCE MODEL ( TAM ), 724729.

Kurniawati, H. A., Winarno, W. A., \& Arif, A. 2017. Analisis Minat Penggunaan Mobile Banking Dengan Pendekatan Technology Acceptance Model ( TAM ) Yang Telah Dimodifikasi, IV(1), 2429.

Kusumaningtyas, R. H., \& Rahajeng, E. (2017). Persepsi nasabah akan layanan atm dan e-banking dengan metode tam, 10(2), 89-102.

Nurmalasari, \& Wulandari, D. (2018). PENGARUH PENGGUNAAN GADGET TERHADAP TINGKAT PRESTASI, 3(2), 111-118.

Rizal, A. (2014). Analisis Penerapan Project Management Information System ( PMIS ) Menggunakan Metode Technology Acceptance Model ( TAM ) Studi Kasus PT . INDOSAT , Tbk. Telekomunikasi Dan Komputer, 5, 124.

Rukmiyati, N. M. S., \& Budiartha, I. ketut. (2016). INFORMASI DAN PERCEIVED USEFULNESS PADA 
KEPUASAN PENGGUNA AKHIR SOFTWARE AKUNTANSI ( STUDI EMPIRIS PADA HOTEL BERBINTANG DI PROVINSI BALI ). Magister Akuntansi Fakultas Ekonomi dan Bisnis, Universitas Udayana ( Unud ), Bali Akuntansi merupakan suatu sist, 1, 115-142.

Satrio, D. B., Su'un, M., \& Rahim, S. (2017). PENGARUH PERSEPSI KEGUNAAN, KEMUDAHAN, DAN KERUMITAN TERHADAP APLIKASI E-FAKTUR DI MAKASSAR, 7.

Siahaan, M. D. L., \& Prihandoko. (2019). Mengukur Tingkat Kepercayaan Sistem Zakat Online Menggunakan Technology Acceptance Model ( TAM ) di Kalangan Masyarakat Kampus, 6.

Suryani, R. (2017). SEBAGAI PENGEMBANGAN MEDIA DAKWAH DALAM MEMBENTUK AKHLAKUL KARIMAH. 